\title{
KEPEMIMPINAN KEPALA SEKOLAH DALAM PENGEMBANGAN
} IKLIM ORGANISASI DAN KERJA GURU

\begin{abstract}
Zainal Fauzi
Dosen FKIP Universitas Islam Muhammad Arsyad Al Banjari Banjarmasin

Jalan Adhyaksa No. 2 Kayu Tangi Banjarmasin 70123

\section{ABSTRACT}

The low quality of education is one of the many national issues in education today. This issue is caused by various factors, one of which is a factor of school leadership. The headmaster as one of the human resources have an important role in the school. the effectiveness of decision-making and policy will determine how the behavior of school leadership. Based on the results of data processing and analysis concluded that (1) there is a significant relationship between the behavior of school leadership and job satisfaction; (2) there is a relationship between organizational climate and job satisfaction; (3) together there is a relationship between the behavior of school leadership and organizational climate and job satisfaction. Based on the results of the study, presented suggestions to the principal in order to improve its ability to plan tasks and assign work procedures but it also can establish good relationships, being warm and appreciate and trust of its members. The school principal is also expected to create a school climate that is as good as their communication, planning, work procedures, and achieving good results.
\end{abstract}

Keywords: leadership behavior, organizational climate, job satisfaction, teacher.

\section{PENDAHULUAN}

Indonesia memerlukan sumberdaya manusia dalam jumlah dan mutu yang memadai sebagai pendukung utama dalam pembangunan. Untuk memenuhi sumberdaya manusia tersebut, perkembangan pendidikan memiliki peran yang sangat penting dalam membentuk karakter warga masyarakat. Hal ini sesuai dengan UU No 20 Tahun 2003 Tentang Sistem Pendidikan Nasional pada Pasal 3, yang menyebutkan bahwa pendidikan nasional berfungsi mengembangkan kemampuan dan membentuk karakter serta peradaban bangsa yang bermartabat dalam rangka mencerdaskan kehidupan bangsa. Pendidikan nasional bertujuan untuk berkembangnya potensi peserta didik agar menjadi manusia yang beriman 
dan bertakwa kepada Tuhan Yang Maha Esa, berakhlak mulia, sehat, berilmu, cakap, kreatif, mandiri, dan menjadi warga negara yang demokratis serta bertanggung jawab. Berdasarkan fungsi dan tujuan pendidikan nasional, jelas bahwa pendidikan di setiap jenjang, harus diselenggarakan secara sistematis guna mencapai tujuan tersebut. Hal tersebut berkaitan dengan pembentukan karakter warga masnyarakat Indonesia dalam lingkungan keluarga dan masyarakat, sehingga manusia Indonesia mampu bersaing, beretika, bermoral, sopan santun dan berinteraksi dengan masyarakat.

Undang-Undang Nomor 22 Tahun 1999 tentang Otonomi Daerah, menghendaki manajemen kepemimpinan kepala sekolah secara efektif, sehingga dalam memberdayakan potensi sekolah secara maksimal dalam rangka mencapai mutu pendidikan yang diharapkan. Acuan pengembangannya diatur dalam Permendiknas no.13 tahun 2007 tentang Standar kualifikasi dan kompetensi seorang kepala sekolah.

Sekolah identik dengan suatu organisasi, dan organisasi tersebut akan berkembang dan mengalami kemajuan sangat ditentukan oleh manejernya. Kompetensi manejer di dalam memainkan peranan manajerialnya akan dapat mewujudkan suatu prestasi dan kalau organisasi tersebut bergerak di bidang bisnis, maka tentunya organisasi tersebut akan memperoleh keuntungan atau benefit yang luar biasa. Demikian pula halnya dengan sekolah, dan sekolah identik pula sebagai sebuah organisasi yang bergerak di dalam membentuk dan menghasilkan SDM. Kemajuan suatu sekolah tidak terlepas dari kompetensi yang dimainkan dan dimiliki oleh kepala sekolah. Semegah apapun dan secanggih apapun sarana dan prasarana yang dimiliki oleh suatu sekolah kalau tidak dimanajemen dan ditangani oleh kepala sekolah beserta dengan aparat birokrasi sekolah yang bersangkutan, maka itu akan sia-sia.

Berbagai upaya peningkatan mutu telah banyak dilakukan baik ditingkat pusat maupun daerah, tetapi pendidikan di Negara kita masih belum seperti yang diharapkan. Rendahnya mutu pendidikan itu salah satunya dapat dilihat dari hasil belajar siswa yang tercermin dari pemerolehan nilai maupun prosentase kelulusan siswa yang mengikuti ujian nasional (UN). Kondisi yang seperti ini tentunya menimbulkan pertanyaan bagi kita. Apakah ada ketidak 
beresan atau kesalahan dalam penyelenggaraan pendidikan di sekolah sehingga hasil proses belajar mengajar tidak sesuai yang diharapkan.

Kepala sekolah dalam melaksanakan kepemimpinan, sebagaimana kepemimpinan pada umumnya, mengemban dua fungsi, yakni fungsi yang berkaitan dengan tugas-tugas dan fungsi yang berkenaan dengan pemeliharaan kelompok (Cartwright, Dorwin dan Zander, Alvi seperti dikutip oleh Hoy dan Miskel 1987), (Sulaiman, 1992). Kedua fungsi ini disebut dimensi struktur inisiasi dan dimensi konsiderasi. Perilaku kepemimpinan kepala sekolah selalu mengarah kepada dua fungsi ini, yakni perilaku yang berorientasi pada tugas dan perilaku yang berorientasi pada bawahan (guru-guru). Kadar perilaku ini bermacam-macam, ada kepala sekolah yang memiliki perilaku tugas, dan perilaku pemeliharaan kelompok yang tinggi keduanya, ada pula yang rendah keduanya, dan ada pula yang rendah pada salah satunya saja.

Motivasi, kinerja maupun kepuasan kerja guru dapat dipengaruhi oleh beberapa factor antara lain adalah iklim organisasi. Di samping itu iklim sekolah merupakan kualitas dari lingkungan sekolah yang terus menerus dialami oleh guru-guru, mempengaruhi tingkah laku mereka dan berdasar pada perilaku kolektif tingkah laku mereka.

Membahas tentang iklim organisasi, kita sebenarnya sedang membahas sifat- sifat atau cirri yang dirasa dalam lingkungan kerja dan timbul terutama karena kegiatan organisasi yang dilakukan secara sadar atau tidak dan yang dianggap mempengaruhi tingkah laku kemudian. Dengan kata lain, iklim dapat dipandang sebagai "kepribadian" organisasi seperti yang dilihat oleh para anggotanya.

Iklim dapat mempengaruhi motivasi, prestasi, dan kepuasan kerja. Iklim mempengaruhi hal itu dengan membentuk harapan pegawai tentang konsekuensi yang akan timbul dari berbagai tindakan. Para pegawai mengharapkan imbalan, kepuasan, frustasi atas dasar persepsi mereka terhadap iklim organisasi. Iklim dapat berada di salah satu tempat pada kontinum yang bergerak dari yang menyenangkan ke arah yang netral sampai dengan yang tidak menyenangkan. Baik pimpinan maupun pegawai menginginkan iklim yang lebih menyenangkan karena maslahatnya, seperti prestasi yang lebih baik dan 
kepuasan kerja.

Kepuasan kerja sebagai kombinasi aspek psikologis, fisiologis, dan kondisi lingkungan yang menyebabkan seseorang dengan menyatakan puas atas pekerjaan atau dengan kata lain sebagai suatu sikap yang dihasilkan dari keseimbangan dan penjumlahan atas berbagai faktor berupa pengalaman yang disukai maupun yang tidak disukai dalam hubungannya dengan pekerjaan yang dilakukan. Kepuasan kerja pada dasarnya merupakan sesuatu yang bersifat individual, setiap individu memiliki tingkat kepuasan yang berbeda-beda sesuai system nilai yang berlaku pada dirinya. Makin tinggi penilaian terhadap kegiatan dirasakan sesuai dengan keinginan individu, maka makin tinggi kepuasannya terhadap kegiatan tersebut. Dengan demikian, kepuasan kerja merupakan evaluasi yang menggambarkan seseorang atas perasaan sikapnya, senang atau tidak senang, puas atau tidak puas dalam bekerja.

\section{LANDASA TEORI}

\section{A. Hubungan Kepemimpinan Kepala Sekolah dengan Kepuasan Kerja Guru}

Salah satu upaya yang dilakukan dalam mengembangkan dan memelihara kualitas kerja guru untuk mengejar prestasi kerja dapat dimulai dengan upaya motivasi. Salah satu factor yang berpengaruh terhadap motivasi kerja guru adalah faktor kepemimpinan. Kepala sekolah sebagai pimpinan di organisasi sekolah seharusnya dapat memotivasi pegawainya, baik itu para guru maupun pegawai biasa, agar dapat berprestasi.

Untuk dapat memotivasi pegawainya, maka seorang kepala sekolah saja harus memiliki kemampuan memimpin, agar apa yang ingin dicapai organisasi sekolah dapat dipahami dan dilaksanakan pegawai. Selain itu, sebagai pemimpin kepala sekolah harus mampu menampilkan ketauladanan, baik dalam bekerja di lingkungan sekolah yang dipimpinnya, juga dalam pergulan di masyarakat.

\section{B. Hubungan Iklim Organisasi dengan Kepuasan Kerja Guru}

Iklim organisasi merupakan suasana dalam suatu organisasi yang diciptakan oleh pola hubungan antar pribadi (interpersonal relationship) yang berlaku. Pola hubungan ini bersumber dari hubungan antar guru dengan guru lainnya atau hubungan guru dengan kepala sekolah tempatnya bekerja atau sebaliknya antara kepala sekolah dengan guru. Iklim yang kondusif sangat 
dibutuhkan oleh guru untuk menumbuhkan dorongan dalam diri untuk bekerja lebih bersemangat.Ini berarti bahwa iklim organisasi berpengaruh terhadap tinggi rendahnya semangat para guru.

\section{Hubungan Kepemimpinan Kepala Sekolah dan Iklim Organisasi dengan Kepuasan Kerja Guru.}

Kepemimpinan kepala sekolah yang professional merupakan suatu hal yang sangat berarti.Seorang guru yang baik, dipimpin oleh kepala sekolah yang baik dan iklim organisasi yang baik. Kondisi ini akan sangat berperan dalam menjalankan tugas sehari- hari yang berkaitan dengan kepuasan kerjanya.

Dengan demikian kepemimpinan kepala sekolah dan iklim organisasi akan mempengaruhi kepuasan kerja guru. Maka dapat disimpulkan bahwa diduga ada hubungan positif antara kepemimpinan kepala sekolah dengan iklim organisasi yang baik dengan kepuasan kerja guru. Dari uraian diatas, diasumsikan bahwa "terdapat hubungan antara kepemimpinan kepala sekolah dan iklim organisasi dengan kepuasan kerja guru."

1. Perilaku kepemimpinan

Yang dimaksud dengan perilaku kepemimpinan kepala sekolah adalah sebagai proses mengarahkan dan mempengaruhi kegiatan yang berhubungan dengan tugas dari anggota sekolah untuk mencapai tujuan sekolah.

Perilaku kepemimpinan kepala sekolah dalam penelitian ini berdasarkan perilaku kepemimpinan menurut The Ohio State University yaitu perilku kepemimpinan dua dimensi yakni (1) Perilaku Inisiasi dan (2) Perilaku Konsiderisasi. Perilaku inisiasi dengan indicator: (a) hubungan tugas antara dirinya sendiri dan anggota kelompok kerja, (b) membangun pola organisasi, jalur komunikasi, dan (c) prosedur-prosedur kerja. Sedangkan perilaku konsiderasi dengan indicator: (a) memperlihatkan persahabatan, (b) saling percaya, (c) penghargaan, (d) keramahan dan (e) kehangatan. (Sulaiman, 1992: 26-27)

\section{Iklim Orgaasi}

Iklim organisasi adalah sejumlah persepsi orang-orang di lingkungan dimana ia bekerja. Selanjutnya persepsi tersebut dapat mempengaruhi perilaku mereka dalam bekerja. Ada enam dimensi iklim yang diteliti berkaitan dengan perilaku 
kepala sekolah dan guru seperti dikemukakan oleh Halpin dan Croft sebagai berikut: (1) Tiga dimensi merupakan perilaku kepala sekolah, yakni: Dukungan/Keterdukungan (supportive); pengarahan langsung/pengawasan melekat (directive); dan membatasil membebani (restrictive). (2) Tiga dimensi lagi merupakan perilaku guru, yakni: Kesejawatan/pertemanan (collegial); keakraban (intimacy); dan keterpisahan/terlepas (disengaged).

3. Kepuasan kerja guru

Kepuasan kerja adalah gambaran tentang sikap dan peranan positif atau negative atau perasaan senang atau tidak senang yang dimiliki seorang pegawai/ karyawan. Kepuasan kerja individu merupakan sesuatu yang individual, masing- masing karyawan (guru) mempunyai tingkat kepuasan yang berbeda-beda sesuai dengan system nilai yang dianutnya. Menurut As'ad (Kabul, 2003:51) tentang faktor-faktor penyebab kepuasan kerja ada beberapa indicator untuk mengukur variable kepuasan kerja yaitu: (1) kesesuaian tugas, (2) kesempatan untuk berprestasi, (3) kesempatan untuk maju, (4) pengakuan dan penghargaan, (5) kondisi kerja.

\section{PEMBAHASAN DAN HASIL PENELITIAN}

\section{Pengertian Kepemimpinan Kepala Sekolah}

Pada dasarnya kepemimpinan merupakan salah satu fungsi manajemen dan sangat penting untuk mencapai tujuan organisasi. Kepemimpinan dihadapkan kepada berbagai aspek seperti: kekuasaan, koalisi, struktur dan kondisi lingkungan. Namun dengan kepemimpinan segala persoalan yang menimpa organisasi dapat diselesesaikan dengan mudah.

Kepemimpinan adalah seni untuk melaksanakan suatu pekerjaan melalui orang lain (Follet dalam Stoner, 1989). Dalam hubungan ini, menurut Fattah (2001:88) pemimpin pada hakikatnya adalah seorang yang mempunyai kemampuan untuk mempengaruhi perilaku orang lain di dalam kerjanya dengan menggunakan kekuasaan.

Kepemimpinan diterjemahkan ke dalam istilah: sifat-sifat, perilaku pribadi, pengaruh terhadap orang lain, pola-pola interaksi, hubungan kerja sama antar peran, kedudukan dan suatu jabatan administrative, dan persepsi dari 
lain-lain tentang legitimasi pengaruh. Kepemimpinan merupakan konsep hubungan manusia dalam spectrum luas yang esensinya bertumpu pada kemampuan mempengaruhi seseorang atau orang lain. Dalam kepemimpinan terdapat unsure pemimpin (leader), anggota (follows), dan situasi (situation) tertentu. (Syafaruddin, 2002:50) Jadi disimpulkan kepemimpinan adalah kegiatan untuk mempengaruhi seseorang atau kelompok agar tercapai tujuan pemimpin tersebut atau organisasi.

Perilaku kepala sekolah dalam penelitian ini adalah perilaku seorang pemimpin yang diperlihatkan melalui cara-caranya memimpin dalam suatu kelompok serta mengupayakan kesejahteraan dan kepuasan kelompok yang dipimpinnya.

\section{Perkembangan Teori Kepemimpinan}

Pada dasarnya kepemimpinan telah dipelajari melalui berbagai teknik yang bervariasi, tergantung pada konsepsi kepemimpinan dan pilihan metodologi para penelitinya. Sementara itu, Robbins (1984), Owens (1987), Hoy and Miskel (1987), Buford and Bedeian (1988) yang dikutip Sulaiman (1992) dalam Abdul Hafiz (2005) menggolongkan dengan tiga pendekatan: (1) pendekatan sifat, (2) pendekatan perilaku dan (3) pendekatan kontingensi atau pendekatan situasional.

\section{Pendekatan Sifat dalam Kepemimpinan}

Pendekatan sifat berfokus pada karakateristik pribadi kepemimpinan, untuk mengetahui sifat-sifat yang membuat seseorang berhasil.Pendekatan ini bertolak dari asumsi bahwa individu merupakan pusat kepemimpinan.Pandangan ini disebut sebagai teori "greatman", menyatakan bahwa seseorang itu dilahirkan membawa atau tidak membawa cirri/sifat (traits) yang diperlukan bagi seorang pemimpin.Pemimpin itu dilahirkan bukan dibuat dan kepemimpinan adalah suatu fungsi dari suatu kualitas seseorang, dari suatu individu, bukan dari suatu situasi, teknologi atau dukungan masyarakat.Hal ini mengandung pengertian dasar penelitian tentang kepemimpinan dengan menyebutkan bahwa individu adalah sumber segala-galanya.

\section{Pendekatan Perilaku dalam Kepemimpinan}

Pendekatan ini memandang bahwa pemimpin yang efektif adalah 
fleksibel, mamapu memilih perilaku kepemimpinan yang sesuai dalam waktu dan situasi tertentu. Bagaimana pemimpin berprilaku akan dipengaruhi latar belakang pengetahuan, nilai-nilai dan pengalaman. Demikian halnya kekuatan bawahan perlu dipertimbangkan oleh pemimpin sebelum menentukan gaya yang cocok. Menurut Tannenbaum pimpinan dapat memberikan partisipasi dan kebebasan dengan pertimbangan: (1) mengharapkan kemerdekaan dan kebebasan berbuat, (2) ingin mempunyai tanggung jawab dalam pengambilan keputusan, (3) mendukung tujuan organisasi, (4) memperoleh pengetahuan dan pengalaman menangani masalah secara efisien, dan (5) mengaharapkan manajemen partisipatif. Sedangkan kekuatan situasional seperti iklim organisasi, sifat tugas, tekanan waktu, sikap bawahan terhadap kekuasan dan faktor lingkungan organisasi.

Menurut Owens (1987), Hoy dan Miskel (1987) menyimpulkan bahwa pada dasarnya perilaku pemimpin dapat digolongkan menjadi dua dimensi. Bukti-bukti yang mereka kumpulkan antara lain: Dorwin Cartwright dan Zander atas dasar temua- temuan pada Research Center for Group Dynamic mendeskripsikan kepemimpinan dalam dua set kelompok fungsi, yakni: (1) Goal Achievment, ialah dimensi yang berkenaan dengan pencapaian beberapa tujuan khusus kelompok; (2) Group Maintenance, yakni dimensi yang berkenaan dengan kegiatan mempertahankan atau memperkuat kelompok itu sendiri. Armitai Etzioni berteori bahwa setiap kolektivitas mesti membutuhkan dua set kebutuhan: (1) Instruemental Needs, yakni mobilisasi sumber-sumber untuk menyelesaikan tugas, dan (2) Expressive Needs, yakni integrasi social dan normative dari anggota kelompok. Berikutnya Bowers dan Seashore mengusulkan empat dimensi dasar dari struktur fundamental kepemimpinan: (1) Support, ialah perilaku yang mempertinggi perasaan pentingnya dan berharganya seseorang, (2) Interaction Facilitation, perilaku yang mendorong anggota kelompok untuk mengembangkan keakraban, hubungan saling memuaskan; (3) Goal Emphasis, perilaku yang mendorong antusiasme untuk mencapai tujuan kelompok dan mencapai performance yang excellence; (4) Work Facillitation, perilaku yang membantu pencapaian tujuan seperti penjadwalan, koordinasi, perencanaan, dan menyediakan sumber-sumber 
seperti peralatan, bahan-bahan, dan pengetahuan teknis. Support dan Interaction Facillitation tergolong dalam dimensi hubungan sedangkan goal emphasis dan work facilitation tergolong dimensi tugas.

\section{Konsep Iklim Organisasi}

Iklim adalah "kondisi, suasana atau keadaan". Sementara itu, organisasi adalah 1) sekelompok orang yang sepakat untuk mematuhi seperangkat normanorma, 2) kelompok kerja yang terdiri dari bagian-bagian atau seksi-seksi dengan subseksi-subseksi dengan bagian tugas masing-masing, 3) system social yang dibentuk untuk mencapai tujuan- tujuan tertentu, 4) wadah yang dibentuk oleh sekelompok orang dengan tujuan tertentu (Kamus besar bahasa Indonesia, 2003). Iklim organisasi merupakan hal yang perlu mendapat perhatian seorang manajer pendidikan (kepala sekolah) karena faktor tersebut sedikitnya ikut mempengaruhi tingkah laku guru, pegawai juga siswa. Dengan demikian hendaknya organisasi yang berkembang secara dinamis akan berdampak positif bagi kelangsungan dan keuntungan organisasi. Keadaan atau suasana sekolah yang tenang dan nyaman, sesuai untuk proses pengajaran dan pembelajaran dianggap sebagai mempunyai iklim sekolah yang kondusif.

Membahas tentang iklim organisasi, kita sebenarnya sedang membahas sifat- sifat atau cirri yang dirasa dalam lingkungan kerja dan timbul terutama karena kegiatan organisasi yang dilakukan secara sadar atau tidak dan yang dianggap mempengaruhi tingkah laku kemudian. Dengan kata lain, iklim dapat dipandang sebagai "kepribadian" organisasi seperti yang dilihat oleh para anggotanya.

Iklim dapat mempengaruhi motivasi, prestasi, dan kepuasan kerja. Iklim mempengaruhi hal itu dengan membentuk harapan pegawai tentang konsekuensi yang akan timbul dari berbagai tindakan. Para pegawai mengharapkan imbalan, kepuasan, frustasi atas dasar persepsi mereka terhadap iklim organisasi.

Sedangkan berkenaan dengan iklim tertutup (closed climate). Hoy dan Miskel mengatakan bahwa iklim tertutup ditandai dengan adanya dorongan (thrust) dan semangat kerja (spirit) yang rendah, serta sikap keterpisahan (disengagement) yang tinggi. Dalam iklim yang demikian ini, kepala sekolah 
dan guru-guru tampaknya asal bekerja kurang kreatif, penyupervisian terhadap guru-guru bersifat tertutup yakni tanpa mengindahkan usulan atau masukan dari guru-guru. Selain itu, kepala sekolah bersifat kurang akrab dan sering membebani guru dengan pekerjaan-pekerjaan yang kurang menyenangkan. Demikian pula pihak guru-guru dengan kepala sekolah, kurang bersungguhsungguh dalam melaksanakan tugasnya dan menghasilkan prestasi yang kurang memuaskan, frustasi dan bersikap apatis. Dengan begitu, sekolah diliputi suasana yang kurang sungguh-sungguh dan tidak efektif dalam pencapaian tujuan organisasi

Dalam perkembangannya, adanya iklim organisasi di atas, mengundang perdebatan dikalangan peneliti. Brown (Hoy dan Miskel, 1987:228) misalnya yang telah mereplekasi penelitian Halpin dan Croft pada 81 sekolah dasar di daerah Minnesota AS telah berhasil mengidentifikasi delapan iklim organisasi yang terentang dalam satu kontinum. Berkenaan dengan hasil penelitian ini, Brown menyimpulkan bahwa walaupun kontinum iklim itu tidak perlu (bagi peneliti) dibagi-bagi menjadi bermacam-macam iklim yang berlainan.

Dalam upaya mengatasi perbedaan-perbedaan tersebut diatas, Hoy dan Miskel (1987:228-229) mengajukan cara yang lebih mudah untuk menentukan tingkat keterbukaan dan ketertutupan relative dari iklim organisasi sekolah, yaitu dengan menggunakan rumus indeks keterbukaan iklim sebagai berikut:

Indeks keterbukaan (openness index) = skor dorongan (thrust score) + skor semangat (spirit score) - skor keterpisahan (disengagement score)

Dari rumus tersebut di atas, dapat dijelaskan bahwa semakin tinggi indeksnya maka semakin cenderung terbuka iklim organisasi sekolah.Lebih lanjut, Hoy dan Miskel pada rumus di atas, didasarkan atas anggapan bahwa ketiga subtes tersebut merupakan karakteristik penting dari tipe iklim terbuka sampai dengan iklim tertutup. Apabila ketiga- tiganya digunakan secara bersamasama maka akan dapat menentukan dan melukiskan profil iklim terbuka dan iklim tertutup sebagaimana dijelaskan oleh Halpin dan Croft di aras. Dengan kata lain, apabila sekolah-sekolah yang memiliki iklim tertutup, maka sekolah yang memiliki iklim terbuka cenderung memiliki skor yang tinggi pada dimensi spirit, intimacy, thrust, consideration serta memiliki skor yang rendah untuk 
E-ISSN : 2580-7056, ISSN : 2580-7064

Pascasarjana IAIN Palangka Raya

dimensi disengagement, aloofness, hindrance, production emphasis.

TABEL 2.1

IKLIM SEKOLAH DAN DIMENSI SUB SKALA

\begin{tabular}{|c|c|c|c|c|c|c|}
\hline More open & & & $\mathrm{Mo}$ & ce closed & & \\
\hline Sub skala & Open & Autonomous & Controlled & Familiar & Paternal & Closed \\
\hline dimensions & & & & & & \\
\hline Hindrance & Low & Low & High & Low & Low & High \\
\hline Intimacy & Modera & High & Low & High & Low & Moder \\
\hline Disengagement & Low & Low & High & High & High & High \\
\hline Espirit & High & High & Low & Low & Low & Low \\
\hline $\begin{array}{l}\text { Production } \\
\text { emnhasis }\end{array}$ & Low & Low & High & Low & High & High \\
\hline Alofness & Low & High & High & Low & High & High \\
\hline Consideration & Low & Moderat & Low & High & High & Low \\
\hline Thrust & High & Moderat & Moderat & Moderat & Moderat & Low \\
\hline
\end{tabular}

Dikutip dari Halpin dan Croft (Sergiovanni, 1987:264)

Selanjutnya, meskipun OCDQ sampai sekarang masih merupakan kuesioner tentang iklim sekolah yang digunakan secara luas, tetapi ada beberapa keterbatasan yang melekat padanya (Hoy dan Miskel 1987:229; Owen 1987:301) sebagai contoh, Sergiovanni dan Starrat (1983:60) meragukan kemampuan OCDQ untuk dipakai peneliti sekolah dasar atau lanjutan yang lebih banyak. Silver (Hoy dan Miskel 1987:229) menyatakan bahwa kerangka konseptual OCDQ memiliki logika kurang jelas, selain itu juga bersifat kurang praktis. Analisis pakar lainnya, Hayes dalam Hoy dan MIskel, menunjukkan bahwa sebagian dari subtes-subtes OCDQ ternyata tidak salah, dan juga kurang handal, sehingga instrument itu secara keseluruhan memerlukan perbaikan. Perbaikan dilakukan oleh Hoy bersama Robert Kottkamp, Sharon Clover, John Feldman dan John Mulhem yang tergabung dalam tim riset dari Rutgers University Amerika Serikat pada tahun 1986, dan hasilnya adalah Revised Organizasional Climate Description Questionaire for Elementary School (OCDQRE) dan Revised Organizasional Climate Description Questionaire for Secondary School (OCDQ-RE).

OCDQ-RE terdiri dari enam subtes yang menggambarkan tiga dimensi 
perilaku guru, yakni kolegial (collegial), keakraban (intimate), keterpisahan (disengagement), serta tiga dimensi perilaku kepala sekolah, yakni suportif (supportive), direktif (directive), dan membatasi (restrictive). Sedangkan OCDQRS terdiri dari lima dimensi iklim sekolah. Dua dimensi pertama menggambarkan perilaku kepala sekolah yaitu suportif (supportive) dan direktif (directive), sedangkan tiga dimensi berikutnya menggambarkan perilaku kerja guru yang keterlibatannya (engaged), frustasi (frustrased), dan keakraban (intimate). (Hoy dan Miskel, 1987:235)

TABEL 2

PROFIL PROTOTIPE JENIS-JENIS IKLIM SEKOLAH

\begin{tabular}{|l|c|c|c|c|}
\hline \multirow{2}{*}{$\begin{array}{l}\text { Climate } \\
\text { dimension }\end{array}$} & \multicolumn{4}{|c|}{ Climate Tipe } \\
\cline { 2 - 5 } Supportive & Open & Engaged & Disengaged & Closed \\
\hline Directive & Low & Low & High & Low \\
\hline Restrictive & Low & High & Low & High \\
\hline Collegial & High & High & Low & High \\
\hline Intimate & High & High & Low & Low \\
\hline Disengaged & Low & Low & High & High \\
\hline
\end{tabular}

Dikuti dari Hoy dan Miskel (1987:233)

\section{A. Iklim Terbuka (open climate)}

Iklim terbuka ditandai dengan adanya kerjasama dan respek diantara pegawai (para guru) dan pemimpin (kepala sekolah).Kerjasama tersebut dapat menciptakan iklim dimana pimpinan mendengarkan dan terbuka terhadap pegawai, pimpinan memberikan hadiah yang benar-benar ikhlas, terus-menerus, dan respek terhadap kemampuan profesionalisme dari para guru (dukungan yang tinggi) serta memberikan kebebasan kepada guru untuk berbuat. Perilaku guru mendukung, terbuka dan hubungan dengan teman sejawat tinggi. Guru menunjukkan pertemanan yang terbuka (intimasi tinggi), dan komitmen terhadap pekerjaan. Singkatnya antara pimpinan (kepala sekolah) dan pegawai (guru) saling terbuka.

\section{B. Iklim Terkendali (enganged climate)}

Iklim terkendali ditandai dengan usaha yang tidak efektif oleh pimpinan untuk mengontrol, dan adanya kinerja professional guru.Pimpinan 
keras dan autokratik, dengan memberikan petunjuk, instruksi, perintah yang tinggi dan tidak respek pada kemampuan professional serta kebutuhan para guru.Selain itu pimpinan menghalangi para guru dengan aktivitas yang berat.Para guru tidak memperdulikan perilaku pimpinan dan memperlakukan diri mereka sendiri sebagai para professional. Mereka satu sama lain saling menghormati dan saling mendukung, mereka bangga akan rekan kerja mereka dan menikmati pekerjaan, mereka benar-benar berteman selain itu guru tidak hanya respek atas kemampuan mereka masing-masing, tetapi mereka juga menyukai satu sama lain (benar-benar intim). Guru sebagai tenaga professional dan produktif walaupun memiliki pimpinan yang lemah, para guru bersatu, komitmen, mendukung dan terbuka.

\section{Iklim Lepas (disenganged climate)}

Iklim ini ditandai dengan adanya perilaku pimpinan yang bersifat terbuka, peduli dan mendukung.Pimpinan mendengarkan dan terbuka terhadap pegawai (guru). Sangat mendukung, memberikan kebebasan terhadap guru untuk berbuat sesuai dengan pengetahuan professional mereka.Namun pegawai (guru) tidak mau menerima pimpinan, guru secara aktif bekerja untuk melakukan sabotase terhadap pimpinan, gur tidak memperdulikan pimpinan. Bukan hanya tidak menyukai pimpinan, tetapi para guru juga tidak respek dan tidak menyukai satu sama lain (intimasi rendah atau hubungan kolega yang rendah). Guru benar-benar terlepas dari tugas-tugas.

\section{Iklim Tertutup (closed climate)}

Pada iklim tertutup, pimpinan dan bawahan benar-benar terlihat melakukan usaha, pimpinan menekankan pekerjaan yang kurang penting dan pekerjaannya sendiri, sedangkan pegawai (guru) merespon secara minimal dan menunjukkan komitmen yang rendah. Kepemimpinan atasan terlihat sebagai pengawas, kaku, tidak peduli, tidak simpatik dan memberikan dukungan yang rendah.Bahkan pimpinan menunjukkan kecurigaan- kecurigaan, kurangnya perhatian terhadap pegawainya, tertutup, kurang fleksibel, apatis dan tidak komitmen.

\section{Kepuasan Kerja}

Kepuasan berasal dari kata "puas" yang berarti senang (lega, terpenuhi 
hasrat hati). As'ad (Kabul, 2003: 41) menyatakan bahwa kepuasan adalah perasaan seseorang terhadap pekerjaannya.Dalam hal ini kepuasan kerja diartikan sebagai reaksi sikap emosi seseorang terhadap suatu pekerjaan. Sedangkan menurut Gorton dikatakan "satisfication and morale are attitudinal variables reflect positive or negative feeling about particular or persons" (1976:165). Di dalam pengertian ini kepuasan kerja diartikan sebagai gambaran tentang variable sikap positif/senang atau sikap negative/tidak senang seorang pegawai terhadap pekerjaannya.

Kepuasan kerja sebagai kombinasi aspek psikologis, fisiologis, dan kondisi lingkungan yang menyebabkan seseorang dengan menyatakan puas atas pekerjaan atau dengan kata lain sebagai suatu sikap yang dihasilkan dari keseimbangan dan penjumlahan atas berbagai faktor berupa pengalaman yang disukai maupun yang tidak disukai dalam hubungannya dengan pekerjaan yang dilakukan.

Kepuasan kerja pada dasarnya merupakan sesuatu yang bersifat individual, setiap individu memiliki tingkat kepuasan yang berbeda-beda sesuai system nilai yang berlaku pada dirinya.Makin tinggi penilaian terhadap kegiatan dirasakan sesuai dengan keinginan individu, maka makin tinggi kepuasannya terhadap kegiatan tersebut.Dengan demikian, kepuasan kerja merupakan evaluasi yang menggambarkan seseorang atas perasaan sikapnya, senang atau tidak senang, puas atau tidak puas dalam bekerja

Berdasarkan pengertian diatas dapat disimpulkan bahwa kepuasan kerja (Job Satisfication) adalah reaksi sikap atau emosi yang menggambarkan hasil persepsi tentang positif/senang atau negative/tidak senang dan sesuai atau tidak sesuai seorang pegawai terhadap pekerjaannya.

\section{Sumber kepuasan kerja}

Sumber kepuasan kerja pada seorang pegawai adalah seperangkat keinginan kebutuhan, hasrat dan pengalaman masa lalu yang menyatu membentuk harapan kerja. Kepuasan kerja menunjukkan kesesuaian antara harapan seseorang yang timbul dan imbalan yang disediakan pekerjaan. Kepuasan kerja umumnya mengacu pada sikap seorang pegawai, kepuasan kerja memiliki banyak dimensi. Ia dapat mewakili sikap secara menyeluruh, atau mengacu pada 
bagian pekerjaan seseorang. Sebagai sekumpulan perasaan, kepuasan kerja bersifat dinamik. Kepuasan kerja dapat menurun secepat timbulnya biasanya lebih cepat sehingga mengharuskan untuk memperhatikan setiap saat

Kepuasan kerja adalah bagian kepuasan hidup, sifat lingkungan seseorang di luar pekerjaan mempengaruhi perasaan didalam pekerjaan. Demikian juga halnya, karena pekerjaan merupakan bagian penting kehidupan, kepuasan kerja mempengaruhi kepuasan hidup seseorang. Hasilnya terdapat dampak bolak-balik (spiilover effect) yang terjadi antara kepuasan kerja dan kepuasan hidup.

Yang termasuk dalam faktor pendorong adalah: prestasi, pengakuan, promosi, tanggung jawab, dan pekerjaan itu sendiri. Yang termasuk dalam faktor-faktor penyehat adalah: gaji, kemungkinan untuk bertumbuh, kedudukan, hubungan antar pribadi dengan atasan, hubungan antar pribadi dengan rekan sejawat, supervise, kebijakan, administrasi, kondisi kerja, kehidupan pribadi, dan kemanan kerja.

Menurut Herzberg, faktor-faktor pendorong adalah penyebab kepuasan (satisfier). Maksudnya ialah apabila facktor-faktor tersebut bisa terpenuhi, akan menimbulkan kepuasan pada seseorang. Sebaliknya apabila faktor-faktor tersebut tidak terpenuhi, maka tidak akan timbul kepuasan kerja. Namun tidak timbulnya kepuasan kerja bukan berarti timbulnya ketidakpuasan kerja.

Faktor penyehat disebut juga penyebab ketidak puasan kerja. Maksudnya adalah apabila faktor-faktor tersebut bisa terpenuhi, akan meniadakan ketidakpuasan. Sebaliknya apabila faktor-faktor penyehat ini tidak bisa dipenuhi, maka akan menyebabkan ketidakpuasan. Namun ketiadaan ketidakpuasan bukan berarti timbul kepuasan kerja. Menurut teori ini, faktorfaktor yang menyebabkan ketidakpuasan tidak saling tumpang tindih dan tidak berkaitan dalam satu kontinum. Masing-masing berdiri dalam kontinum sendiri.

Sikap dan reaksi demikian itu disebut moral. Moral adalah reaksi mental dan emosional dari seseorang terhadap pekerjaannya. Seseorang dapat dikatakan mempunyai moral kerja yang tinggi apabila merasa puas dengan pekerjaannya, memiliki semangat, rasa tanggung jawab, dan antusiasme. Sebaliknya tingginya absensi, dating terlambat, sering menghindar dari tanggung jawab menunjukkan moral kerja yang rendah. 
Dengan demikian, kepuasan kerja guru dalam melaksanakan tugasnya akan diperolehnya apabila: adanya kesesuaian tugas, pemberian tugas seuai aturan, adanya dukungan untuk berprestasi, adanya dukungan untuk memajukan sekolah, adanya kesempatan untuk maju, memperoleh penghargaan dari masyarakat, adanya perhatian dari masyarakat, dilibatkan dalam kegiatan sekolah, adanya kenyamanan dilingkungan kerja, adanya ketenangan atau kepuasan batin, serta kondisi kerja yang mendukung

\section{KESIMPULAN}

Simpulan yang dapat diambil dari hasil-hasil penelitian tersebut yaitu Terdapat gambaran hubungan perilaku kepemimpinan kepala sekolah dan iklim organisasi dengan kepuasan kerja guru dapat dijelaskan bahwa: (1) Tanggapan guru-guru terhadap kepemimpinan kepala sekolah termasuk pada katagori lemah; (2) Tanggapan guru-guru terhadap iklim organisasi termasuk pada katagori lemah (3) Tanggapan guru-guru terhadap kepuasan kerja guru termasuk pada katagori memuaskan. Sehingga simpulan ini dapat dijelaskan sebagai berikut: (1) Hubungan antara Perilaku Kepemimpinan Kepala Sekolah dengan Kepuasan Kerja Guru sangat lemah (tidak signifikan). Hubungan tersebut menunjukan adanya pengaruh yang lemah perilaku kepemimpinan kepala sekolah (X1) terhadap kepuasan kinerja guru (Y) dengan koefisien korelasi sebesar 0.163 dan memberilkan kontribusi besar serta sisanya dipengaruhi oleh faktor lain. (2) Hubungan antara Iklim Organisasi sekolah dengan Kepuasan Kerja Guru sangat lemah (tidak signifikan). Hubungan tersebut menunjukan adanya pengaruh yang tidak baik antara iklim organisasi sekolah (X2) terhadap kepuasan kinerja guru (Y) dengan koefisien korelasi sebesar 0,626. Meskipun hubungan ini termasuk katagori rendah, tetapi dapat diartikan bahwa iklim organisasi sekolah memberikan kontribusi besar dan sisanya dipengaruhi oleh faktor lain. (3) Terdapat derajat Hubungan perilaku kepemimpinan kepala sekolah dan iklim organisasi secara umum dan bersama-sama memberikan kontribusi yang berarti (signifikan) terhadap kepuasan kerja guru. Hubungan perilaku kepemimpinan kepala sekolah (X1) dan iklim organisasi (X2) dengan kepuasan kerja guru (Y) sangat kuat dengan koefisien korelasi sebesar 0,543. Dan hubungan perilaku kepemimpinan kepala sekolah dan iklim organisasi 
E-ISSN : 2580-7056, ISSN : 2580-7064

Pascasarjana IAIN Palangka Raya

secara umum memberikan pengaruh terhadap kepuasan kerja guru besar dan sisanya dipengaruhi oleh faktor lain.

\section{DAFTAR PUSTAKA}

Arikunto, Suharsimi, 1996. Dasar-dasar Evakuasi Pendidikan, Jakarta: Bumi Aksara.

Burhanuddin, 2002. Manajemen Pendidikan: Wacana, Proses dan Aplikasinya di

Sekolah Malang: Universitas Negeri Malang.

Hafiz, Abdul. 2005. Hubungan Prilaku Kepemimpinan Kepala Sekolah dengan Mutu Lulusan pada SMP Negeri se Kota Banjarmasin, Tesis. Banjarmasin: Manajemen Pendidikan.

Kabul. 2003. Faktor-faktor yang Mempengaruhi Kinerja Guru SLTP di Kota Banjarmasin. (tesis), Yogyakarta: Program Pascasarjana, Universitas Negeri Yogyakarta.

Kunandar, 2007. Guru Profesional, Implementasi KTSP dan Persiapan Menghadapi Sertifikasi Guru, Jakarta: Grafindo Persada.

Moedjiarto, F. Gaffar, (2002). Fungsi Manajemen Pendidikan dalam Mengelola Pendidikan di Daerah otonom, Jakarta.

Ngalimun. 2013. Perkembangan dan Pengembangan Kreativitas. Yogyakarta: Aswaja Pressindo.

Smith, John. 1988. Penilaian Pelaksanaan dan Pengembangan Karyawan. Jakarta: Pustaka Binaman Pressindo.

Sugiyono, 2006. Metode Penelitian Pendidikan Pendekatan Kuantitatif, Kualitatif dan $R \& D$. Bandung: Alfabita

Supardi dan Anwar, Syaiful. 2002. Dasar-dasar Perilaku Organisasi. Jogjakarta: UII Press.

Syarifuddin, 2002. Manajemen Mutu Terpadu dalam Pendidikan. Jakarta: Grasindo.

Thoha, M. 2002. Perilaku Organisasi. Jakarta: Raja Drafindo Persada.

Wahjosumidjo 2002. Kepemimpinan Kepala Sekolah. Jakarta: Raja Grafindo Perkasa 